\title{
Are State Corporate Income Tax Rates Too High? A Panel Study of Statewide Laffer Curves
}

\author{
John Stinespring \\ The University of Tampa
}

\begin{abstract}
This paper estimates the impact of corporate income tax rates on corporate tax revenue at the state level over the period 1996-2007 to determine the existence and shape of a Laffer curve for state corporate income taxes. Standard theoretical constructs are used to characterize corporate income tax revenues as a quadratic function of the corporate tax rate. Empirical results using linear, log-log, and semi-log econometric models provide mixed support for the hypothesis of the existence of a state corporate income tax Laffer curve. To isolate the behavioral changes implicit in the Laffer curve theory, nonbehavioral factors that affect the tax base, such as state tax policies (revenue apportionment and throwback rules) and state spending policies (percentage of government revenues allocated to government infrastructure expenditures) are controlled. Results show the existence of a Laffer curve and that its revenue-maximizing rate has declined over time. The rates range from $8.52 \%$ to $9.32 \%$ for the time period $1996-2002$ and $6.03 \%$ to $7.47 \%$ over the time period $2003-2007$. These values indicate that 8 states were taxing on the right side of their Laffer curve in 2002, and 22 states were taxing on the right side of their Laffer curve in 2007. The policy implication is that these states could have experienced higher tax revenues with a lower tax rate.
\end{abstract}

Keywords corporate income taxation; corporate income tax revenues; Laffer curves 


\section{Introduction}

The global recession that began in 2007 has wrecked havoc on the government budgets of individual states in the U.S. States have seen their tax revenues fall while their spending needs have risen. As consumer expenditures have declined dramatically, business investment has fallen in tow. To stimulate economic activity, various tax cuts have been proposed at both the federal and state levels. One that has gained traction is the proposal to decrease the state corporate income tax (SCIT) rate. It has been suggested that the SCIT is inefficient due to the distortions it creates in the economy and that lower SCIT rates are often associated with greater investment and higher wages. Tax-cut proponents argue that reductions in the SCIT rate would spur business investment and slow, if not stem, the steady increase in unemployment. For example, the governor of Rhode Island, Donald Carcieri, has proposed a four-year phase out of its 9\% SCIT rate to become "competitive and attract new and existing businesses". Some economists and politicians have suggested these effects may be so large that SCIT revenues may actually rise with decreased rates. In other words, current SCIT rates may be on the "right side" of a SCIT Laffer curve. Whether or not this is true depends first upon whether a Laffer curve exits for the SCIT.

The theory supporting the corporate tax Laffer curve is that changes in CIT rates affect firm behavior and by such behavior, the tax base. Behavioral changes manifest themselves via decisions on investment, employment, employee compensation, location, and compliance. A significant body of empirical support exists for these claims. Early literature on these effects focus on the federal corporate income tax (FCIT) beginning with Harberger (1966) who estimated that the distortions created by it sum 
to a cost of about 24 percent of FCIT revenues. Later researchers have estimated the costs of the FCIT to exceed half of the revenues it generates (see Gravelle (1994) and Fullerton and Rogers (1993)). Measures of the marginal efficiency cost of the FCIT - that is, the cost of raising one additional dollar of tax revenue from it - further bolsters the idea. Jorgensen and Yun (1991) provide a widely-cited estimate of the FCIT marginal efficiency cost of $\$ 0.45$ compared to $\$ 0.52$ for income taxes, $\$ 0.38$ for payroll taxes and $\$ 0.26$ for sales taxes. ${ }^{1}$ Estimates of the compliance costs of the FCIT are also large, estimated at 5.9 percent of firm tax expenses (Slemrod and Blumenthal (1996)). This percentage is about double the federal corporate income tax percentage cost (Gupta and Mills (2002)).

At the state level, Harden and Hoyt (2003) show that state and local taxes negatively affect employment levels and that the SCIT has the largest negative impact on employment growth. ${ }^{2}$ Regarding employee compensation, Gyourko and Tracy (1989) find that a one percentage point increase in the SCIT rate reduces annual wages by approximately one percent for 125 U.S. cities in 1980. Their results are only tempered by an updated and expanded study by Felix (2009) who finds an average reduction of 0.57 percent in wages for a one percentage point increase in SCIT rate over the period in this paper, 1997-2005. Location decisions are also negatively affected by higher SCIT rates. Newman (1983) found that differences in SCIT rates influenced the movement of industry to southern states where rates were lower. A later study by Agostini and Tulayasathein (2001) found the SCIT rate to be the most influential tax on investment decisions by foreign corporations. Empirical evidence suggests that compliance is negatively related to SCIT rates (see $\gg>>$ ). Such behavioral responses support the existence of a Laffer curve.

Though there are many empirical studies of CIT Laffer curves at the national and international level, no tests of a Laffer curve have been conducted at the state-wide level. This is surprising as statewide comparisons do not suffer from many of the problems inherent to cross-country comparisons. In 
particular, individual states within the U.S. experience similar technology, inflation rates, banking and financial regulation, labor market conditions, capital mobility and many other conditions that are not shared across countries. Moreover, the data itself is likely to be collected in a more consistent manner across states than across countries. Within this consistency there exists sufficient variability in rates and tax revenues over states and over time to provide a robust data set.

This paper follows standard theoretical constructs by modeling the impact of SCIT rates on corporate revenues as a quadratic function for the years 1996-2007. Total SCIT revenues, both in absolute terms and as a percentage of real gross state product, are used as dependent variables. Empirical results using linear, log-log, and semi-log econometric specifications support the hypothesis of the existence of a Laffer curve whose revenue-maximizing SCIT rate has declined over time. The rates range from $8.52 \%$ to $9.32 \%$ for the time period $1996-2002$ and $6.03 \%$ to $7.47 \%$ over the time period 2004-2007. These values indicate that 8 states were taxing on the right side of their Laffer curve in 2002, while 22 states were taxing on the right side of their Laffer curve in 2007 . The policy implication is that these states could have experienced higher tax revenues with a lower tax rate.

The paper is organized as follows. Section 2 examines the literature on CIT Laffer curves. Section 3 presents the model. Section 4 examines the data and methodology. Section 5 presents empirical results. Section 6 concludes.

\section{Literature on Laffer Curves}

One of the early econometric studies of Laffer curves in the United States is Hsing (1994). Using national data for the U.S. from 1959-1991, Hsing regressed real personal income tax revenue against the average personal income tax rate using linear, log-log and semi-log specifications. He found a 
statistically significant quadratic Laffer curve for personal income taxes with a revenue-maximizing tax rate between $32.67 \%$ and $35.21 \%$. Studies of Laffer curves for CIT rates follow a similar procedure but incorporate multiple countries over multiple time periods. Regression results from these pooled data sets have revealed a statistically significant Laffer curve exists for corporate taxes. Clausing (2007), for example, uses OECD data to compare FCIT revenue as a percentage of GDP to FCIT rates for 29 countries over 24 years between 1979 and 2002. Her results show the existence of a statistically significant Laffer curve for FCIT and a revenue-maximizing tax rate of 33\%. Brill and Hassett (2007) build on the work of Clausing by, among other things, using data from 1980-2005 and allowing for lags in the impact of FCIT rates on FCIT revenues. Using OECD data, they show that the revenuemaximizing corporate tax rate was approximately $34 \%$ in the late 1980 s but declined to $26 \%$ for the period 1990-2005. This paper applies and extends the various econometric specifications of Hsing (1994), Clausing (2007) and Brill and Hassett (2007) to SCIT data.

\section{The Model}

The impact of CIT rates on firm profits and decisions on investing, location, and employee compensation are extensive. The literature reveals the relationship to be complex and nonlinear. Rather than attempt to estimate these individual impacts on firm behavior, the CIT Laffer curve captures the firms' behavioral responses in a simple, reduced form. To model the relationship, it will be necessary to control for factors that are non-behavioral but may significantly affect the tax base. Three such factors are the throwback rule, apportionment formula, and a state's allocation of its revenues.

The apportionment formula arose because many corporations operate in multiple states simultaneously. The formula is used to divide a multi-state firm's income among the states with which 
the firm has sufficient contact. Each state must determine what fraction of a company's income was earned in its state and therefore subject to their CIT. The fraction depends on the state's apportionment formula which provides weights for three factors: company payroll, property, and sales. For example, a state with a $100 \%$ weight on company payroll would not collect taxes from companies that sell to that state but do not have any reported workers there. Another state might weight them equally: $33 \%$ payroll, $33 \%$ property, and $33 \%$ sales. The trend has been toward a heavier weight on sales. An apportionment formula divides a multistate firm's taxable income, $\pi_{i}$, among its different jurisdictions. Firm $i$ 's tax expense, $x_{i}$, is given by

$$
x_{i}=t_{i}^{S C I T} *\left[w_{i}^{S} * \frac{s_{i}}{S}+w_{i}^{L} * \frac{l_{i}}{L}+w_{i}^{P} * \frac{p_{i}}{P}\right] * \pi_{i}
$$

where $t_{i}^{S C I T}$ is the statutory SCIT rate in state $i ; s_{i}, l_{i}$, and $p_{i}$ are the firm's sales, payroll, and property in state $i$, while $S, L$, and $P$ are the firm's total sales payroll, and property; and $w_{i}^{s}, w_{i}{ }^{L}, w_{i}^{P}$ are the factor weights in state $i$ for sales, payroll, and property, respectively, that sum to 1 . Recent research suggests the throwback and allocation rules are important to firm behavior. For example, Gupta and Hofmann (2003) find that marginal capital investment in the manufacturing sector is affected most by the throwback requirement, the apportionment weights and by the state income tax rate itself. In particular, Gupta and Hofmann (2003) find that the SCIT rate has a significant negative impact on firm investment in manufacturing. Using state data from 1983 to 1996, the authors show that a one percent decrease in the "property burden" (the product of the property factor weight times the SCIT) results in a 0.05 to 0.35 percent increase in new capital spending. The authors also conclude that the lack of a throwback rule is viewed as a major incentive for business investment. 
The throwback rules exists because many corporations sell their products in states where they do not have a physical presence and the sales income in such states is not apportioned to any state for tax purposes. Almost one half of states impose a throwback rule which allows the corporation's state of domicile to claim the untaxed sales income for tax purposes.

A government's allocation of its revenues may also have a significant impact on firm behavior and the shape of the Laffer curve. For example, a government that spends more on public capital than government consumption will have a higher Laffer curve whose peak is skewed rightward, ceteris paribus. The higher Laffer curve arises because greater revenues are generated by public capital for any tax rate and the rightward skew indicates that fewer self-financing tax cuts - that is, tax cuts that occur on the right-side of the Laffer curve peak - exist. (See Stinespring (2005))

SCIT revenues received by state $i$ at time $t$, Revenue $_{i, t}$, are expressed as a quadratic function of that state's tax rates at time $t$, Rate $_{i, t}$. To control for non-behavioral factors we incorporate a dummy variable for the throwback rule, $\lambda_{i t}$ ( 1 if state $i$ in year $t$ had a throwback rule; 0 otherwise), a dummy variable for the apportionment formula ( 1 if state $i$ in year $t$ had an a throwback rule; 0 otherwise), a a vector of state-specific variables, $\theta_{i}$ and a period-specific variable, $\gamma_{t}$, in the form

$$
\text { Revenue }_{i, t}=f\left(\text { Rate }_{i, t}, \text { Rate }_{i, t}^{2}, \theta_{i}, \gamma_{t}\right)
$$

Assuming a positive coefficient for Rate $_{i, t}$ and a negative one for Rate $_{i, t}{ }^{2}$, the function will have the following bell-like shape shown in Figure 1. 


\section{[Figure 1 Here]}

With SCIT revenues on the vertical axis and the SCIT rate on the horizontal, the Laffer curve is graphed as an inverted hyperbola whose peak occurs at the point $t^{\text {Rev-Max }}, \mathrm{R}^{\max }$. As logic requires, both a SCIT rate of zero and $100 \%$ will create no revenues. SCIT rates to the right and left of $t^{\text {Rev-Max }}$ result in lower tax revenues. Any marginal tax cut starting from a point to the right of the peak will raise revenues. Any marginal tax cut starting from a point to the left of the peak will lower revenues.

To estimate the SCIT Laffer curve, four econometric specifications are used. The first is the familiar linear form which serves as the benchmark specification and is given by

$$
\text { Revenue }_{i, t}=\theta_{i}+\gamma_{t}+\beta_{1} \text { Rate }_{t}+\beta_{2} \text { Rate }_{t}^{2}+e_{t}
$$

where $e_{t}$ represents the error term that is approximately normally distributed with a variance of $\sigma^{2}-$ i.e., $e_{t} \sim N\left(0, \sigma^{2}\right)-$ and it is assumed $\beta_{1}>0, \beta_{2}<0$ to generate the bell shape shown in Figure 1. For the linear specification, the peak of the Laffer curve occurs where $-\frac{\beta_{1}}{2 \beta_{2}}$. Any state whose top SCIT rate is above this rate is on the right side of the Laffer curve. At such a position, a decrease in tax rates will incentivize firm production and investment such that the SCIT base expands and tax revenues rise.

The benchmark linear specification is compared to the following three functional forms. 


$$
\begin{aligned}
& \ln _{\text {Revenue }_{i, t}}=\theta_{i}+\gamma_{t}+\alpha_{1} \text { lnRate }_{t}+\alpha_{2}\left(\text { lnRate }_{t}\right)_{\square}^{2}+e_{t} \\
& \ln _{\text {Revenue }}^{i, t}=\theta_{i}+\gamma_{t}+\chi_{1} \text { Rate }_{t}+\chi_{2} \text { Rate }_{t \square}^{2}+e_{t} \\
& \text { Revenue }_{i, t}=\theta_{i}+\gamma_{t}+\delta_{1} \text { lnRate }_{t}+\delta_{2}\left(\text { lnRate }_{t}\right)_{\square}^{2}+e_{t}
\end{aligned}
$$

Whereas the coefficient in (2) represented a slope estimate, the coefficient in the log-log form, (3), represents the elasticity of tax revenues to tax rates. Revenue-maximizing tax rates for equations (3) and

(5) are found as $e^{-\frac{\alpha_{1}}{2 \alpha_{2}}}$ and $e^{-\frac{\delta_{1}}{2 \delta_{2}}}$, respectively while the revenue-maximizing tax rate for (4) follows the linear model with $-\frac{\chi_{1}}{2 \chi_{2}}$.

\section{Data and Methodology}

The sample consists of data from 50 states over eleven years, from 1996 to 2007 giving a total of 600 (50*12) observations. Data on SCIT revenue and gross state product come from the Bureau of Economic Analysis and are collected in the Tax Foundation's Facts and Figures on Government Finance. ${ }^{3}$ To account for high correlation between the size of the state population and the size of SCIT revenues, SCIT revenues per capita are used. Data on state populations and top marginal tax rates are provided by the Bureau of the Census and the Commerce Clearing House. To account for inflation's effect on SCIT revenues, per capita SCIT revenues are divided by the GDP deflator as calculated by the Bureau of Economic Analysis. Data on total state government expenditures and state infrastructure comes from the Bureau of the Census and are adjusted for inflation. Infrastructure expenditures are comprised of Highways, Air Transportation (Airports), and Sea and Inland Port Facilities. Data on individual state throwback rules and apportionment weights come from the Commerce Clearing House. 
Table 1 shows correlation coefficients for the variables. If variables are too highly correlated with one another, as indicated by a correlation absolute value above 0.50 , separating the individual effects of each variable on revenues may be difficult. The highest correlation appears between the state throwback rule (THRWBCK) and federal government throwback rule (USTHRWBCK) at 0.78. Regressions that include both suffer from multicollinearity and Most states which require a throwback also require ...

Table 1
\begin{tabular}{|c|c|c|c|c|c|c|c|c|}
\hline & INFRA_GOV & REALREVPOP & RGDP & RRATE & USTHRWBCK & THRWBCK & UN & APPRT \\
\hline INFRA_GOV & 1.000000 & 0.205811 & $-\mathbf{0 . 4 6 6 9 9 6}$ & 0.091912 & $\mathbf{0 . 3 0 7 7 2 1}$ & 0.133451 & -0.093519 & $-\mathbf{0 . 3 4 3 9 0 9}$ \\
\hline REALREVPOP & 0.205811 & 1.000000 & 0.067524 & 0.284125 & 0.048643 & 0.082613 & 0.139346 & -0.104999 \\
\hline RGDP & -0.466996 & 0.067524 & 1.000000 & 0.052596 & -0.223006 & -0.152990 & 0.187676 & $\mathbf{0 . 3 8 7 3 3 0}$ \\
\hline RRATE & 0.091912 & $\mathbf{0 . 2 8 4 1 2 5}$ & 0.052596 & 1.000000 & -0.101799 & -0.188832 & -0.017782 & 0.083285 \\
\hline USTHRWBCK & 0.307721 & 0.048643 & -0.223006 & -0.101799 & 1.000000 & $\mathbf{0 . 7 7 9 8 9 1}$ & 0.038051 & -0.274164 \\
\hline THRWBCK & 0.133451 & 0.082613 & -0.152990 & -0.188832 & $\mathbf{0 . 7 7 9 8 9 1}$ & 1.000000 & 0.008730 & $-\mathbf{0 . 3 9 9 2 4 0}$ \\
\hline UN & -0.093519 & 0.139346 & 0.187676 & -0.017782 & 0.038051 & 0.008730 & 1.000000 & 0.030907 \\
\hline APPRT & -0.343909 & -0.104999 & $\mathbf{0 . 3 8 7 3 3 0}$ & 0.083285 & -0.274164 & $\mathbf{- 0 . 3 9 9 2 4 0}$ & 0.030907 & 1.000000 \\
\hline
\end{tabular}

Different estimates of the relevant SCIT rate are possible as some states have flat tax rates and others graduated. The common procedure for time-series national studies and panel estimates of international CIT rates is to use the top tax rate for reporting and analysis which is sensible if the majority of corporate revenues are subject to the top SCIT rate. ${ }^{4}$ The same practice has been used in statewide studies such as Felix (2009) and Gupta et al (2009). ${ }^{5}$ As such, the top corporate tax rate most likely represents the marginal tax rate and is very near the average tax rate. This is important as the marginal tax rate affects a company's expansion decisions while the average determines total tax revenues. $^{6}$

Some states allow deductions of federal corporate income taxes paid. As such, the relevant top SCIT rate must account for the percentage of federal deductibility. Alabama and Louisiana granted 
$100 \%$ federal deductibility while Iowa and Missouri granted 50\% deductibility. North Dakota allowed $100 \%$ deductibility until 2004 when the deduction was eliminated. With the federal corporate income tax rate given by $35 \%$, the actual SCIT rate used in this paper may be specified as

$$
t^{S C I T}=\left(1-t_{d}^{*} 0.35\right) * t^{S C I T}{ }_{\text {NOMINAL }}
$$

where $t_{d}$ represents the percentage of federal tax SCIT deductibility. For example, corporations in Iowa faced a nominal SCIT rate of $12 \%$ in 2005 but were allowed to deduct $50 \%$ of federal corporate taxes paid. The actual SCIT rate was therefore $9.9 \%$ as derived by $t^{S C I T}=(1-0.5 * 0.35) * 0.12$.

Over the eleven years studied, Iowa maintained the highest top nominal corporate tax rate at 12 percent. The most populous state, California, had the highest total SCIT revenues while Alaska maintained the largest revenues in per capita terms. Thirty-two states kept their SCIT rates unchanged, seven raised their rates, and eleven lowered them. North Dakota saw the largest relative decrease from 10.5 to 7 percent while Indiana saw the largest relative increase from 3.4 to 8.5 percent. Five states Nevada, South Dakota, Texas, Washington, Wyoming - had no SCIT. ${ }^{7}$ The least populous state, Vermont, had the lowest nonzero SCIT revenues per person over the time period.

Three states appeared as outliers. The first, Alaska, was an outlier because its per capita SCIT revenue exceeded 3 standard deviations from the mean. The New York data aggregates local and SCIT revenue making comparisons difficult with the other states that do not follow that practice. The third outlier, Michigan, used a value added-type tax with a much broader tax base then a SCIT, making comparisons with other state's CIT rates invalid. ${ }^{8}$ For these reasons, the econometric models were run on three sets of data. The first set includes all states (50); the second set, all states with nonzero SCIT rates (45 states); the third set excludes all zero SCIT rate states and outliers (42 states). ${ }^{9}$ 
Figure 2 shows the mean and median SCIT rates and revenues per year using the 45-state data set from 1996-2007 excluding 2003. The left-side vertical axis shows real revenues per capita per year while the right-side vertical axis shows tax rates in percentages.

\section{[Figure 2 Here]}

The figure appears to illustrate a change in the relationship between rates and revenues between the two periods. In particular, both rates and revenues trended downward from 1996-2002 but then revenues experienced a steady increase from 2004-2007..$^{10}$ This change in trends supports the notion of a structural break in the data at 2003 which was found to be statistically significant using the Chow Test. $^{11}$ All model specifications had $F$ values that exceeded the critical $F$ values and therefore support the existence of a structural break. In addition, the $t$-stats, $\bar{R}^{2} \mathrm{~s}, F$-stats, and Durbin-Watson statistics were much lower (and in some cases insignificant) for all econometric specifications using the entire 1996-2007 period. Thus, the models used are divided between the 1996-2002 period and the 2004-2007 period.

Both a state-specific effect and period-specific effect that alter the Laffer curve's intercept were found to be statistically significant for all regressions at the $0.0001 \%$ level, except the linear-log model. $^{12}$ A fixed effects specification was chosen over a random effects model because the former applies when the cross sectional units are assumed not to be random drawings from a larger population. This clearly holds when comparing states. ${ }^{13}$ Finally, all errors were corrected using a White's (diagonal) correction method.

\section{Empirical Results}


There are many econometric results shared by all of the models applied to the 1996-2002 and 2004-2007 time periods. The only model specification with poor predictive power is the linear-log given by equation (5). For all tests, the linear-log model produced low $t$-stats and (relatively) low Durbin-Watson values. All other model specifications yield results that 1) have residuals that appear to be normally distributed, 2) have high $\bar{R}^{2}$ and $F$-stat values, 3) show no evidence for multicollinearity and 4) show stationarity. The relevant results of each regression appear in tables below.

\section{[Table 1 Here]}

The Jarque-Bera (JB) test was used to examine the normality of the residuals for all models. For the linear model, the JB score reveals that only 4 states had a JB probability below 0.20 for the 50 states used. The JB score for the nonlinear model also produced only 4 JB probabilities below 0.20 for the 45 states used. The JB score must be considered in light of the limitation of 11 values per state. The revenue-to-GSP models produced similar results. Specifically, no estimations resulted in more than 2 states with JB probabilities below 0.20. On these grounds, the assumption of normally distributed residuals is not rejected.

All model specifications seemed to provide a good fit to the data as evidenced by all regressions having an $\bar{R}^{2}$ greater than 0.82 and most exceeding 0.90 . In addition, the associated $F$-stats had $p$ values of nearly zero. The combination of high $\bar{R}^{2}$ and $F$-stats with high $t$-stats indicated that multicollinearity was not a problem. The Levin, Lin and Chu (2002) test for unit roots in the dependent variables indicates that both dependent variables were stationary over the 1996-2002 and 2004-2007 periods. ${ }^{14}$ Nearly all Durbin-Watson values were within ranges to suggest neither autocorrelation nor modeling misspecification exists. ${ }^{15}$

[Table 2 Here] 
Several criteria were used to test the various functional forms. The first consideration was $\bar{R}^{2}$. Because $\bar{R}^{2}$ is not comparable for different dependent variables adjustments were made to the goodnessof-fit measures to compare the log-log and linear models (Gujarati p.219). Neither log-log nor linear model $\bar{R}^{2}$ s appeared significantly better than the other after the appropriate adjustments. Next, the MacKinnon, White and Davidson test was applied to the linear and log-log models to compare the functional forms. Again neither model proved better than the other. In the end, the linear, log-log, and log-linear models all appear to be robust using both real SCIT revenues per capita and real SCIT revenues per capita over GSP as dependent variables. Taken together, these models show a relatively narrow, and statistically significant, range for the revenue-maximizing SCIT rate for the 1996-2002 period and the 2003-2007 period. These results provide strong support for the existence of a SCIT Laffer curve. Plots of these Laffer curves are shown in Figures 3 and 4. Figure 3 shows the range of estimated SCIT Revenues-Per-Capita Laffer Curves for 1996-2002. The taller Laffer curve is from the linear model which gives the revenue-maximizing SCIT rate of $9.32 \%$; the lower is from the $\log -\log$ model which gives the revenue-maximizing SCIT rate of $8.52 \%$.

\section{[Figure 3 Here]}

Figure 4 shows the range of estimated SCIT Revenues/GSP Laffer Curves for 2004-2007. The taller Laffer curve is from the linear model which gives the revenue-maximizing SCIT rate of $6.03 \%$; the lower is from the log-linear model which gives the revenue-maximizing SCIT rate of $7.46 \%$. Though the Laffer curve heights are notably different, it is important to note that the peak tax rates are very near one another.

\section{[Figure 4 Here]}




\section{Conclusion}

This paper provides a first-cut analysis of the impact of corporate income tax cuts on government revenues at the state level. The topic is timely as at least 47 states are facing significant budget shortfalls in the midst of the current recession. ${ }^{16}$ Some state politicians have suggested that lowering rates to stimulate business activity will improve state finances. For example, West Virginia lowered its corporate income from $9 \%$ to $7.5 \%$ in 2008 to avoid "indirectly taxing West Virginia shareholders through lower returns to their investments ... and West Virginia employees through lower wages and fewer jobs". ${ }^{17}$ If the increase in investment returns, jobs, and wages is large enough, the tax base expands and revenues can rise. Other states, such as Illinois, argue for raising their SCIT rate - from $7.35 \%$ to $9.7 \%$ - to spur revenues. Whether tax revenues will rise from a tax cut or a tax increase depends upon the shape of the Laffer curve and whether the current tax rate lies on the left or right of its peak. This paper sheds light on the issue by 1) providing evidence for a statistically significant SCIT Laffer curve at the state-wide level and 2) parameterizing its shape.

Linear, log-log, and log-linear models indicate that the revenue-maximizing SCIT rates range from $8.52 \%$ to $9.32 \%$ for the time period $1996-2002$ and $6.03 \%$ to $7.47 \%$ over the time period 2004 2007. Theory suggests that states with CIT rates above these values may be able to cut their CIT tax rates and spur enough firm investment, employment and wage growth to actually raise their CIT revenues. Using the upper bound value of $7.47 \%, 22$ states were taxing on the right side of the SCIT Laffer curve in 2007. Since that time, three of those states, New Hampshire, Vermont and West Virginia have lowered their CIT rates (though they still remain on the right side of the Laffer curve) while one state, Maryland, has joined the other 22 by increasing its SCIT rate from $7 \%$ to $8.3 \%$ in that time. Illinois, on the other hand, is taxing on the left side of the SCIT Laffer curve. Its proposed 2.4 
percentage point increase, however, would put it well to the right of the Laffer peak. This paper predicts that, ceteris paribus, SCIT revenues will rise for the three tax-cutting states while Maryland's and Illinois' CIT revenues will decline.

\section{References}

Agostini, Claudio and Soraphol Tulayasathien. 2001. “Tax Effects on Investment Location: Evidence

for Foreign Direct Investment in the United States." Office of Tax Policy Research, University of Michigan Business School.

Barro, Joshua. 2008. "2009 State Business Tax Climate Index.” Background Paper (Tax Foundation, October 2008, number 58) pp.12, Table 3.

Brill, Alex and Hassett, Kevin A. 2007. "Revenue-Maximizing Corporate Income Taxes: The Laffer Curve in OECD Countries”, AEI Working Paper \#137, American Enterprise Institute, July 31, 2007.

Clausing, Kimberly A., 2007. "Corporate Tax Revenues in OECD Countries”, International Tax and Public Finance, (14):115-133.

Clemens, Jason, Niels Veldhuis, and Milagros Palacios. 2007. “Tax Efficiency: Not All Taxes Are Created Equal.” Studies in Economic Prosperity. The Fraser Institute, Number 4, January 2007.

Djankov, Simeon, Ganser, Tim, McLiesh, Caralee, Ramalho, Rita, and Andrei Shleifer. 2008. "The Effect of Corporate Taxes on Investment and Entrepreneurship”, NBER Working Paper No. 13756.

Facts and Figures on Government Finance. 2003, Tax Foundation $37^{\text {th }}$ Edition

Felix, Alison R. 2009 “Do State Corporate Income Taxes Reduce Wages?” Economic Review. Federal Reserve Bank of Kansas City, Second quarter, 2009, pp 77-102. 
Fullerton, Don and Rogers, Diane Lim. 1993. "Who Bears the Lifetime Tax Burden?" Washington, D.C.: Brookings Institution.

Gravelle, Jane C. 1994. The Economic Effects of Taxing Capital Income (Cambridge, Mass.: MIT Press, 1994), pp. 75-93

Gujarati, Damodar N. 2003. Basic Econometrics (McGraw Hill-Irwin: 2003).

Gupta, Sanjay, Moore, Jared, Gramlich, Jeffrey, and Hofmann, Mary Ann. 2009. "Empirical Evidence on the Revenue Effects of state corporate Income Tax Policies," National Tax Journal Vol. 62, No. 2 pp. 237-267.

Gupta, Sanjay and Hofmann, Mary Ann. 2003. "The Effect of State Corporate Tax Apportionment and Tax Incentives on New Capital Expenditures" Journal of the American Taxation Association, Vol.25, Supplement, 2003, pp. 1-25.

Harberger, Arnold C. 1966. "Efficiency Effects of Taxes on Income from Capital," in Marian Krzyzaniak, ed., Effects of the Corporate Income Tax, Wayne State University Press, pp. 107-117.

Harden, J. William and Hoyt, William H. 2003. "Do States Choose Their Mix of Taxes to Minimize Employment Losses?” National Tax Journal Vol.56, No. 1 (part 1) pp. 7-26, March

Hsing, Yu. 1996. "Estimating the Laffer Curve and Policy Implications", Journal of Socio-Economics, Vol. 25 (No.3) pp. 395-401.

Johansson, Åsa, Heady, Christopher, Arnold, Jens, Brys, Bert and Vartia, Laura. "Tax and Economic Growth," OECD Economics Department Working Paper No. 620, July 11, 2008.

Jorgensen, Dale W., and Kun-Young Yun. 1991. “The Excess Burden of Taxation in the United States”, Journal of Accounting and Finance 6 (4): 487-508.

Levin, Andrew, Lin, Chien-Fu, and Chu, Chia-Shang James. 2002. "Unit Root Tests in Panel Data: Asymptotic and Finite-Sample Properties,” Journal of Econometrics, 108 (1):1-224. 
MacKinnon, J., White, H., and Davidson, R. 1983. “Tests for Model Specification in the Presence of Alternative Hypothesis; Some Further Results," Journal of Econometrics, Vol. 21: 53-70.

Newman, Robert J. 1983. "Industry Migration and Growth in the South," Review of Economics and Statistics, Vol. 65, No. 1: 76-86.

Savin, N.E. and White, K.J. 1977. "The Durbin-Watson Test for Serial Correlation with Extreme Sample Sizes or Many Regressors," Econometrica (45): 1989-1996.

Slemrod, Joel and Blumenthal, Marsha “The Income Tax Compliance Cost of Big Business," Public Finance Quarterly 24, No.4 (October, 1996):411-38. 
Figure 1

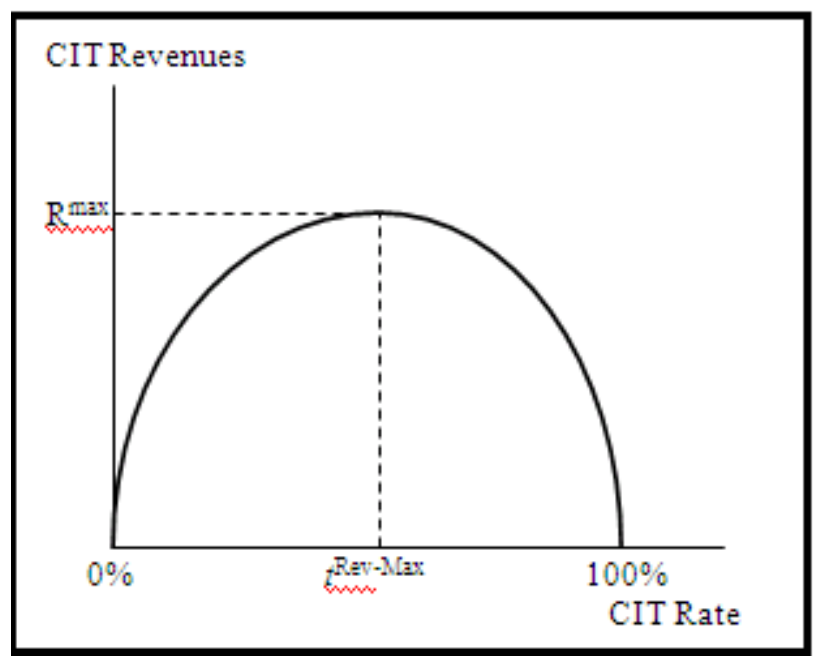

Figure 2

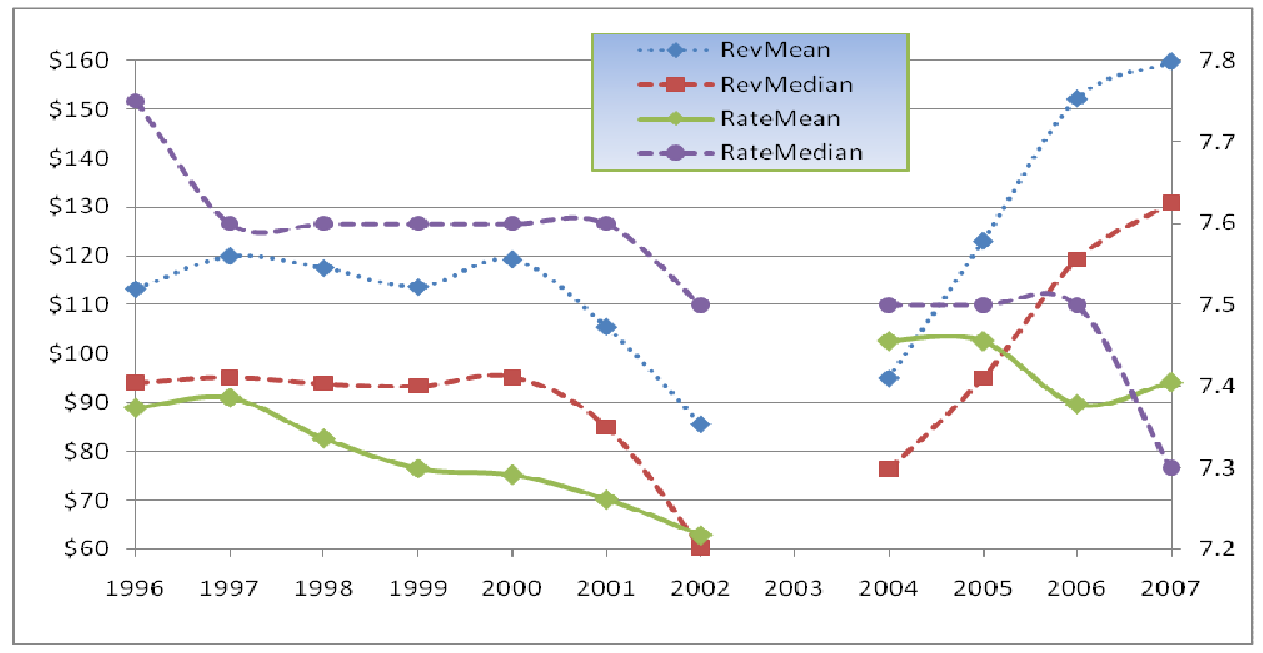


Table 1

Estimated Regressions for the State-Wide CIT Laffer Curves using Real CIT Revenues Per Capita

\begin{tabular}{|c|c|c|c|c|c|c|c|c|}
\hline Data Period & Model & Sample Size & Rate & Rate $^{2}$ & Constant & $\begin{array}{r}\text { Adjusted } \\
R^{2}\end{array}$ & $\begin{array}{l}\text { Durbin- } \\
\text { Watson }\end{array}$ & Tax Rate MAX $^{\text {MAX }}$ \\
\hline \multicolumn{9}{|l|}{ 1996-2002 } \\
\hline & Linear & 42 States & $\begin{array}{r}0.264 \\
(2.123)^{* *}\end{array}$ & $\begin{array}{r}-0.015 \\
(-2.13)^{* *}\end{array}$ & $\begin{array}{r}-0.923468 \\
(-1.827920)^{*}\end{array}$ & 0.95 & 1.23 & $8.82 \%$ \\
\hline & & 45 States & $\begin{array}{r}125.65 \\
(3.64)^{* *}\end{array}$ & $\begin{array}{r}-5.2 \\
(-2.55)^{* *}\end{array}$ & $\begin{array}{r}-500.79 \\
(-3.63)^{* *}\end{array}$ & 0.90 & 1.95 & $12.08 \%$ \\
\hline & Log-Log & 42 States & $\begin{array}{r}20.688 \\
(1.162)\end{array}$ & $\begin{array}{r}-4.827 \\
(-1.093)\end{array}$ & $\begin{array}{r}-17.032 \\
(-0.9697)\end{array}$ & 0.82 & 1.54 & $8.52 \%$ \\
\hline & Log-Linear & 42 States & $\begin{array}{r}2.657 \\
(2.005)^{* *}\end{array}$ & $\begin{array}{r}-0.153 \\
(-1.838)\end{array}$ & $\begin{array}{r}-6.105 \\
(-1.239)\end{array}$ & 0.83 & 1.645 & $8.67 \%$ \\
\hline & & 45 States & $\begin{array}{r}1.017 \\
(2.678)^{* * * *}\end{array}$ & $\begin{array}{r}-0.040 \\
(-1.786)^{*}\end{array}$ & $\begin{array}{r}-0.55 \\
(-0.35)\end{array}$ & 0.81 & 1.58 & $12.93 \%$ \\
\hline \multicolumn{9}{|l|}{ 2004-2007 } \\
\hline & Linear & 42 States & $\begin{array}{r}48.449 \\
(5.772)^{* * *}\end{array}$ & $\begin{array}{c}-3.356 \\
(-5.844)^{* * *}\end{array}$ & $\begin{array}{l}-48.798 \\
(-1.580)\end{array}$ & 0.93 & 1.684 & $7.22 \%$ \\
\hline & & 45 States & $\begin{array}{r}40.216 \\
(5.684)^{* * * *}\end{array}$ & $\begin{array}{c}-2.745 \\
(-3.85)^{* * *}\end{array}$ & $\begin{array}{l}-5.423 \\
(-0.159)\end{array}$ & 0.90 & 1.231 & $7.33 \%$ \\
\hline & $\log -\log$ & 42 States & $\begin{array}{r}5.497 \\
(5.2435)^{* *}\end{array}$ & $\begin{array}{c}-1.4395 \\
(-5.0863)^{* * *}\end{array}$ & $\begin{array}{r}-0.5276 \\
(-0.546)\end{array}$ & 0.89 & 1.582 & $6.75 \%$ \\
\hline & & 45 States & $\begin{array}{r}5.522 \\
(5.272)^{* * * *}\end{array}$ & $\begin{array}{c}-1.446 \\
(-5.12)^{* * *}\end{array}$ & $\begin{array}{c}-0.44 \\
(-0.46)\end{array}$ & 0.91 & 1.53 & $6.75 \%$ \\
\hline & Log-Linear & 42 States & $\begin{array}{r}0.45 \\
(4.793)^{* *}\end{array}$ & $\begin{array}{c}-0.030 \\
(-4.86)^{* *}\end{array}$ & $\begin{array}{c}3.03 \\
(8.618)^{* *}\end{array}$ & 0.89 & 1.569 & $7.47 \%$ \\
\hline & & 45 States & $\begin{array}{r}0.453 \\
(4.809)^{* *}\end{array}$ & $\begin{array}{c}-0.0303 \\
(-4.88)^{* *}\end{array}$ & $\begin{array}{c}3.106 \\
(8.9024) * *\end{array}$ & 0.91 & 1.513 & $7.47 \%$ \\
\hline
\end{tabular}

\footnotetext{
* Significant at the $10 \%$ level, ** Significant at the 5\% level, *** Significant at the $1 \%$ level
} 
Table 2

Estimated Regressions for the State-Wide CIT Laffer Curves using Real CIT Revenues/Gross State Product

\begin{tabular}{|c|c|c|c|c|c|c|c|c|}
\hline Data Period & Model & Sample Size & Rate & Rate $^{2}$ & Constant & $\begin{array}{r}\text { Adjusted } \\
R^{2}\end{array}$ & $\begin{array}{l}\text { Durbin- } \\
\text { Watson }\end{array}$ & Tax Rate ${ }^{\mathrm{MAX}}$ \\
\hline \multicolumn{9}{|l|}{$1996-2002$} \\
\hline & Linear & 42 States & $\begin{array}{r}230.452 \\
(2.263)^{* *}\end{array}$ & $\begin{array}{r}-12.61 \\
(-2.023)^{* *}\end{array}$ & $\begin{array}{r}-856.90 \\
(-2.20)^{* *}\end{array}$ & 0.89 & 1.63 & $9.15 \%$ \\
\hline & & 45 States & $\begin{array}{r}0.163 \\
(1.398)\end{array}$ & $\begin{array}{r}-0.0094 \\
(-1.43)\end{array}$ & $\begin{array}{r}-0.472 \\
(-0.999)\end{array}$ & 0.93 & 2.20 & $8.69 \%$ \\
\hline & $\log -\log$ & 42 States & $\begin{array}{r}24.74 \\
(1.42)\end{array}$ & $\begin{array}{r}-5.747 \\
(-1.327)\end{array}$ & $\begin{array}{r}-28.32 \\
(-1.65)^{*}\end{array}$ & 0.82 & 1.54 & $8.60 \%$ \\
\hline & Log-Linear & 42 States & $\begin{array}{r}2.928 \\
(2.276)^{* * *}\end{array}$ & $\begin{array}{r}-0.168 \\
(-2.068)^{* *}\end{array}$ & $\begin{array}{r}-14.21 \\
(-2.982)^{* *}\end{array}$ & 0.97 & 1.67 & $8.71 \%$ \\
\hline & & 45 States & $\begin{array}{r}2.155 \\
(1.74)^{*}\end{array}$ & $\begin{array}{l}-0.121 \\
(-1.54)\end{array}$ & $\begin{array}{r}-11.20 \\
(-2.47)^{* *}\end{array}$ & 0.96 & 1.93 & $8.94 \%$ \\
\hline \multicolumn{9}{|l|}{ 2004-2007 } \\
\hline \multirow{2}{*}{\multicolumn{2}{|c|}{ Linear }} & 42 States & $\begin{array}{r}0.176 \\
(6.307)^{* * * *}\end{array}$ & $\begin{array}{r}-0.0144 \\
(-6.069) * * *\end{array}$ & $\begin{array}{r}-0.333 \\
(-4.626)\end{array}$ & 0.95 & 1.459 & $6.11 \%$ \\
\hline & & 45 States & $\begin{array}{r}0.152 \\
(4.491)^{* * * *}\end{array}$ & $\begin{array}{r}-0.0126 \\
(-4.75)^{* * *}\end{array}$ & $\begin{array}{r}-0.206 \\
(-2.083)^{* * *}\end{array}$ & 0.92 & 1.17 & $6.03 \%$ \\
\hline & Log-Log & 42 States & $\begin{array}{r}5.2673 \\
(5.408) * * *\end{array}$ & $\begin{array}{r}-1.3798 \\
(-5.294)^{* * *}\end{array}$ & $\begin{array}{r}-7.459 \\
(-8.23)^{* * *}\end{array}$ & 0.98 & 1.60 & $6.75 \%$ \\
\hline & & 45 States & $\begin{array}{r}5.280 \\
(5.456)^{* * * *}\end{array}$ & $\begin{array}{r}-1.383 \\
(-5.345)^{* * *}\end{array}$ & $\begin{array}{r}-7.396 \\
(-8.284)^{* * *}\end{array}$ & 0.98 & 1.56 & $6.74 \%$ \\
\hline & Log-Linear & 42 States & $\begin{array}{r}0.431324 \\
(4.827)^{* * *}\end{array}$ & $\begin{array}{r}-0.029 \\
(-4.974) * * *\end{array}$ & $\begin{array}{r}-4.045 \\
(-11.93)^{* * *}\end{array}$ & 0.97 & 1.59 & $7.46 \%$ \\
\hline & & 45 States & $\begin{array}{r}0.432 \\
(4.855)^{* * * *}\end{array}$ & $\begin{array}{r}-0.029 \\
(-5.012)^{* * *}\end{array}$ & $\begin{array}{r}-4.004 \\
(-11.97) * * *\end{array}$ & 0.98 & 1.55 & $7.46 \%$ \\
\hline
\end{tabular}

\footnotetext{
* Significant at the $10 \%$ level, ** Significant at the 5\% level, *** Significant at the $1 \%$ level
} 
Figure 3

Estimated CIT Revenues-Per-Capita Laffer Curves for 1996-2002

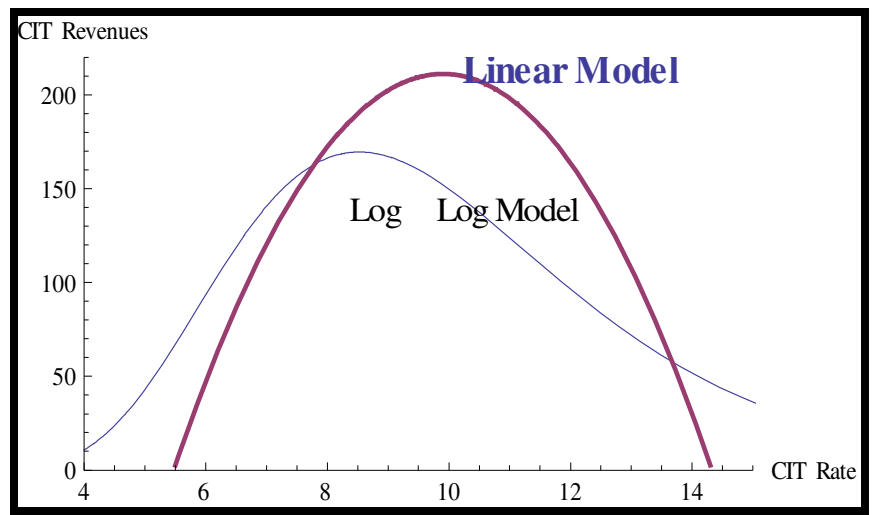

Figure 4

Estimated CIT Revenues/GSP Laffer Curves for 2004-2007

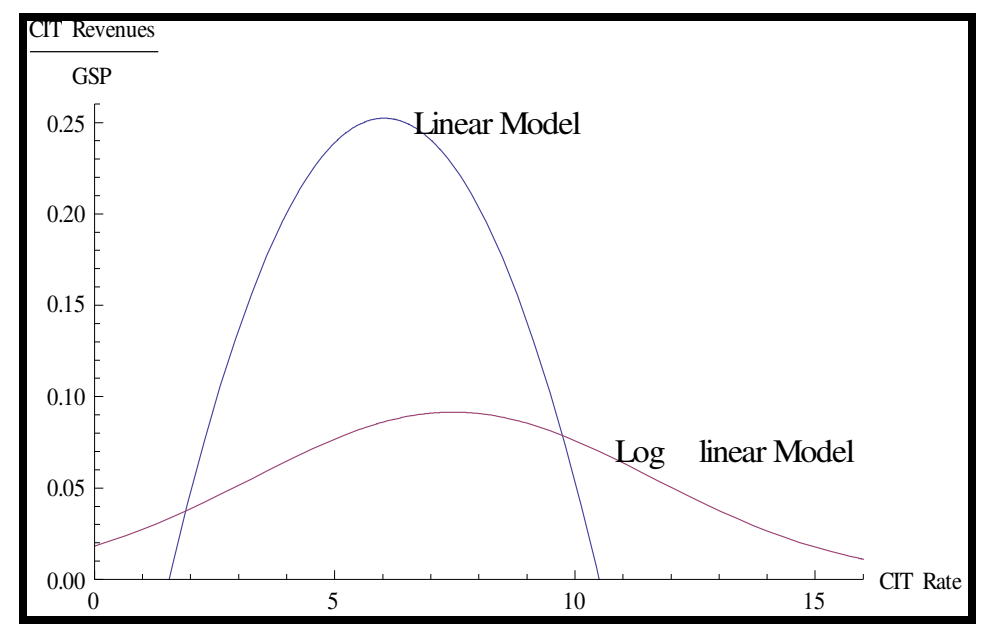




\section{Notes}

${ }^{1}$ These estimates are post-1986 tax reform. Pre-tax reform estimates, which are often quoted, are $\$ 0.84$ for FCIT, $\$ 0.62$ for income taxes, $\$ 0.48$ for payroll taxes and \$0.26 for sales taxes (Jorgensen and Yun (1991)).

${ }^{2}$ Evidence of the harm caused by CIT rates at the national level confirms the state-level impacts. A 2008 OECD study found that "corporate taxes are found to be most harmful for growth" and that "investment is adversely affected by corporate taxation through the user cost of capital". Looking at individual firms, the authors concluded that "lowering the corporate tax rate may be particularly beneficial for productivity growth of the most dynamic and innovative firms" (OECD Working Paper, 2008). A recent NBER Working paper found higher CIT rates discouraged entrepreneurship, foreign direct investment and economic growth (NBER Working Paper No. 13756).

${ }^{3}$ SCIT revenues are collected by the Tax Foundation and presented in the relevant tables under State Tax Collections by Source by State (\$Thousands). Facts and Figures on Government Finance, p. 231, Table E30.

${ }^{4}$ SCIT rates are defined as "Taxes on net income of corporations, including distinctively imposed net income taxes on special kinds of corporations (e.g., financial institutions) and on unincorporated businesses." Facts and Figures on Government Finance, p.334

${ }^{5}$ This idea is supported by Gupta et al (2009) who write "As a practical matter, progressive tax rates are of little consequence since the top statutory marginal rates are reached a fairly low income levels". Some empirical studies use the average tax rate calculated as total SCIT revenues divided by total profits. This creates a problem of endogeneity as the tax rate itself is determined by tax revenues. Using top statutory SCIT rates avoids this problem.

${ }^{6}$ Many states have alternate business taxes, federal deductibility, and other provisions that affect the marginal business tax rate faced by businesses. To determine the correlation between the top statutory SCIT rate and the overall business tax, I compared the SCIT to the Tax Foundation's Business Tax Climate Index which captures these additional tax rate factors (Barro 2009). The statutory SCIT rate has a correlation of approximately 0.60 to the Business Tax Climate Index, thus providing confidence in the SCIT measure.

${ }^{7}$ In 2006, Texas enacted a tax on "net taxable earned surplus" which was repealed in 2007 and replaced with a $1 \%$ tax on gross receipts (rather than profits). Washington also lacks a SCIT and instead has a gross receipts tax known as a "Business and Occupation Tax". The data sources used herein consider these to be different enough from the standard SCIT structure as to analyze them as a zero SCIT state.

${ }^{8}$ The Michigan tax was referred to as a Single Business Tax, SBT and was replaced in 2008 with the Michigan Business Tax which includes a traditional SCIT and a value added tax.

9 The estimated Laffer curve parameter values do not vary significantly for the different data sets providing greater confidence in the conclusions.

${ }^{10}$ To get a sense of the substantive difference in the time periods, the correlation coefficients between CIT rates and revenues were approximately 0.7 for the $1996-2002$ period and -0.75 for the $2003-2007$ period.

11 The derived $F$-statistic is given by $\frac{\frac{\left(R S S_{R}-R S S_{U R}\right)}{k}}{\frac{R S S_{U R}}{\left(n_{1}+n_{2}-2 k\right)}} \sim F_{[k, n 1+n 2-2 k]}$, where $R S S_{R}$ refers to the restricted model; $R S S_{U R}$, the

unrestricted model; $k$ the number of parameters estimated; $n_{1}$ and $n_{2}$ the number of observations for the first and second period, respectively.

12 This was determined using restricted $F$ tests on the joint significance of the fixed effects. The $p$-values for all models were approximately zero.

${ }^{13}$ See Gujarati 2003 (p.650) for a discussion on fixed effects versus random effects model for statewide panel studies.

${ }^{14}$ Applying the method to panel data allows for a test of a common unit root that is shared by each cross section of data. None were found to be statistically significant at the $5 \%$ confidence level. 
${ }^{15}$ The critical values (using the highest number of regressors-21) estimated by Savin and White: for $n=168$, the lower bound $\left(d_{L}\right)$ is 1.48983 and the upper bound $\left(d_{U}\right)$ is 2.01739; for $n=180, d_{L}=1.51636$ and $d_{U}=2.00587$; for $n=290, d_{L}=$ 1.66204 and $d_{U}=1.95587$; for $n=320, d_{L}=1.68540$ and $d_{U}=1.95024$.

${ }^{16}$ McNichol, Elizabeth and Lav, Iris J. "State Budget Troubles Worsen" Center on Budget and Policy Priorities, May, 2009.

${ }^{17}$ Dubay, Curtis S. "What West Virginia Needs to Do in Order to Compete in the 21 st Century" Speech before W. Virginia legislature on December 2006. 